\title{
POSTERIOR EPIDURAL MIGRATION OF SEQUESTERED LUMBAR DISC FRAGMENT CAUSING CAUDA EQUINA SYNDROME
}

\author{
MIGRAÇÃO EPIDURAL POSTERIOR DE FRAGMENTO DE DISCO LOMBAR SEQUESTRADO \\ QUE CAUSA SIINDROME DA CAUDA EQUINA
}

\section{MIGRACIÓN EPIDURAL POSTERIOR DE FRAGMENTO DE DISCO LUMBAR SECUESTRADO QUE CAUSA SIINDROME DE CAUDA EQUINA}

Abolfazl Rahimizadeh ${ }^{1}$, Housain Soufiani ${ }^{1}$, Ava Rahimizadeh ${ }^{1}$

\begin{abstract}
Posterior epidural migration (PEM) of a sequestered free lumbar disc fragment is rare. The rarity is due to presence of several anatomical restraints which restrict a free fragment to move to the posterior compartment. This unusual presentation of disc herniation appeared in the literature either as a single case report or in small series from two to six cases. Herein two new demonstrative cases will be presented with a brief review of the literature.
\end{abstract}

Keywords: Cauda equina; Intervertebral disc displacement; Intervertebral disc; Surgical procedures, operative.

RESUMO

A migração epidural posterior (PEM) posterior epidural migration de fragmento de disco lombar livre sequestrado é rara. A raridade deve-se à presença de várias restrições anatômicas que impedem que o fragmento livre se mova para o compartimento posterior. Essa apresentação incomum de hérnia de disco apareceu na literatura como relato de caso único ou em pequenas séries de dois a seis casos. Neste artigo, são apresentados dois novos casos demonstrativos, com uma breve revisão da literatura.

Descritores: Cauda equina; Deslocamento do disco intervertebral; Disco intervertebral, Procedimentos cirúrgicos operatórios.

RESUMEN

La migración epidural (PEM) posterior Epidural Migration de fragmento de disco lumbar libre secuestrado es rara. La rareza se debe a la existencia de varias restricciones anatómicas impidiendo que el fragmento libre se mueva hacia el compartimento posterior. Esa presentación no común de hernia de disco apareció en la literatura como un relato de caso único o en pequeñas series de dos a seis casos. En este artículo, se presentan dos casos nuevos demostrativos, conjuntamente con una revisión breve de la literatura.

Descriptores: Cauda equina; Desplazamiento del disco intervertebral; Disco intervertebral; Procedimientos quirúrgicos operativos.

\section{CASE 1}

A 53- year old male was admitted because of weakness of the lower extremity and inability to void for a day. He described no considerable history in the last few weeks. Neurological examination showed some decrease strength score of 3/5 on dorsiflexion of both feet. The sensation of the saddle area was also disturbed with bladder dysfunction necessitating a Foley catheter

Magnetic Resonance Image (MRI) revealed an isointense mass located posterior to the theca at L3-L4 level. It had the intensity relative to the intensity of the intervertebral disc showed in T1-weighted sagittal images (Figure 1a). The mass had heterogeneous intensity in T2-weighted sagittal and axial images (Figure $1 \mathrm{~b}$ and $1 \mathrm{c}$ ).

The patient underwent surgery within a few hours later with diagnosis of ligamentum flavum or synovial cyst. Surprisingly, after L3 laminectomy a big disc fragment lying on the dura mater was found. The fragment's disc which was loosely adhered to the dura was detached with careful dissection (Figure 1d).

Subsequently, the corresponding disc space which had a tear in its annulus was approached and degenerated disc material was removed.

The patient was discharged with partial recovery a few days after surgery, however, he fully recover a month later.

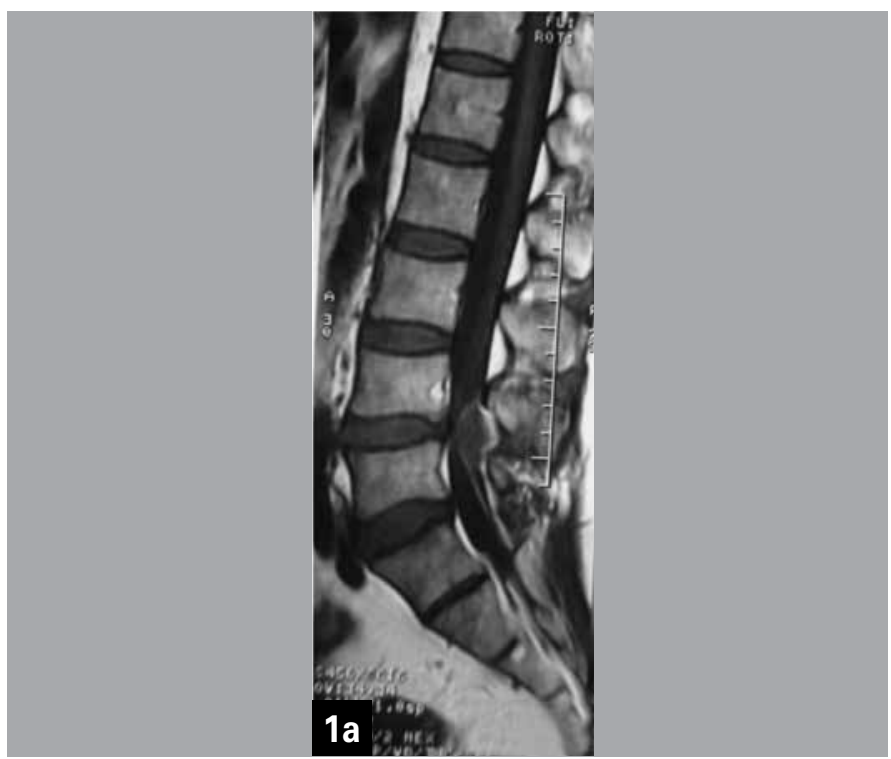

Figure 1a. T1-weighted image showing a posteriorly located mass at the level of L3- L4- it is isointense relative to intervertebral disc. ( L5 is sacralized)

1. MD, Department of Spinal Surgery, Pars Hospital, Tehran, Iran. 


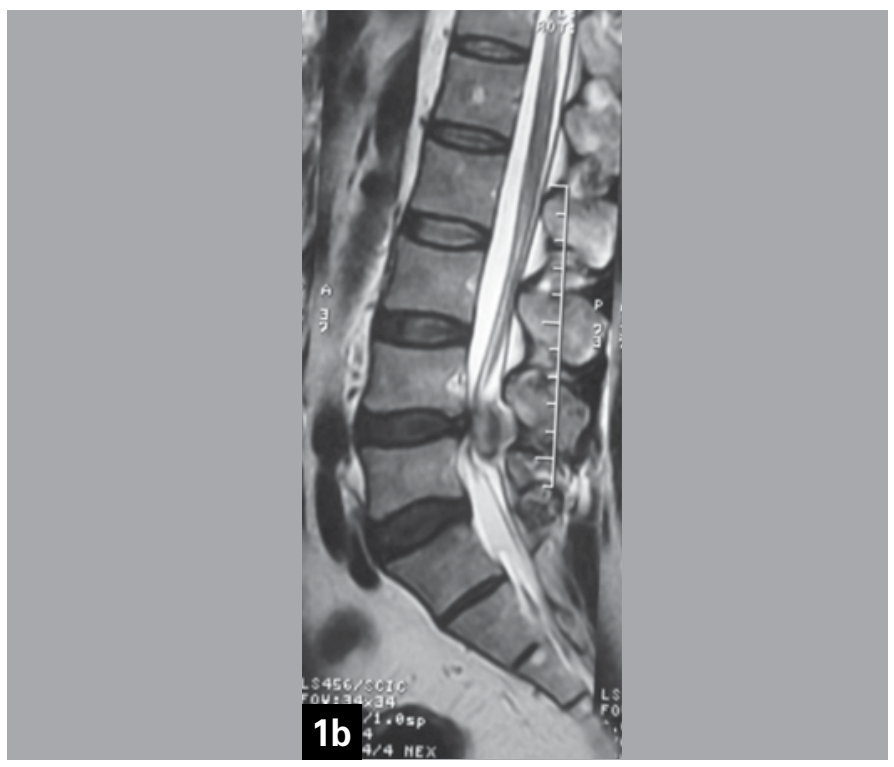

Figure 1b. T2 -weighted sagittal image. Demonstrating a mass located posterior to the theca at same level.

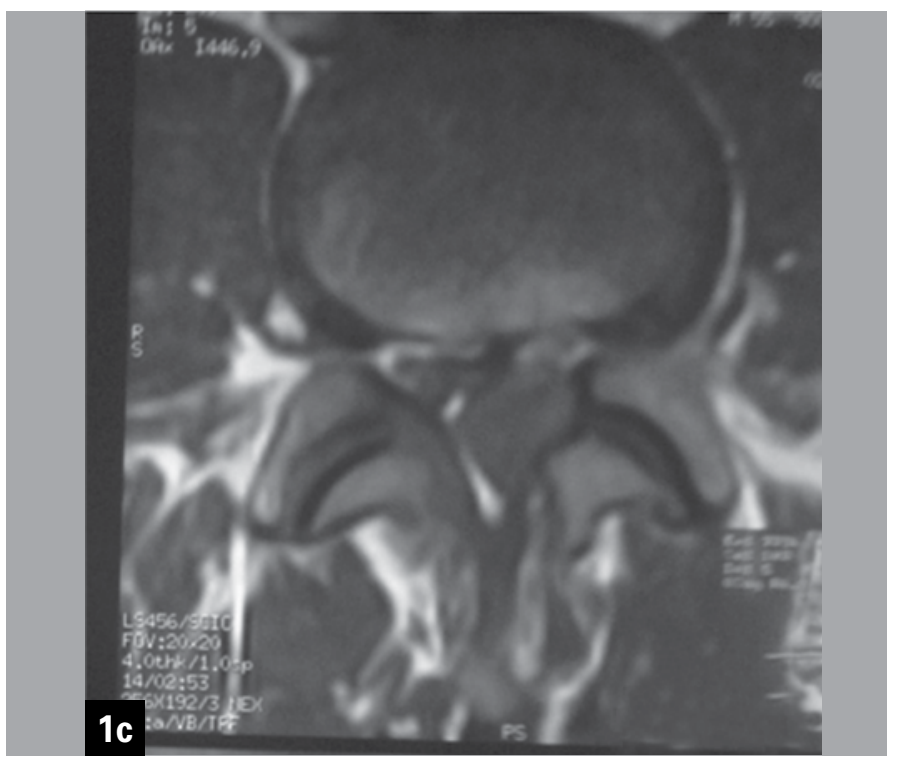

Figure 1c: T2-Weighted Axial view at the same level showing a central posteriorly located mass.

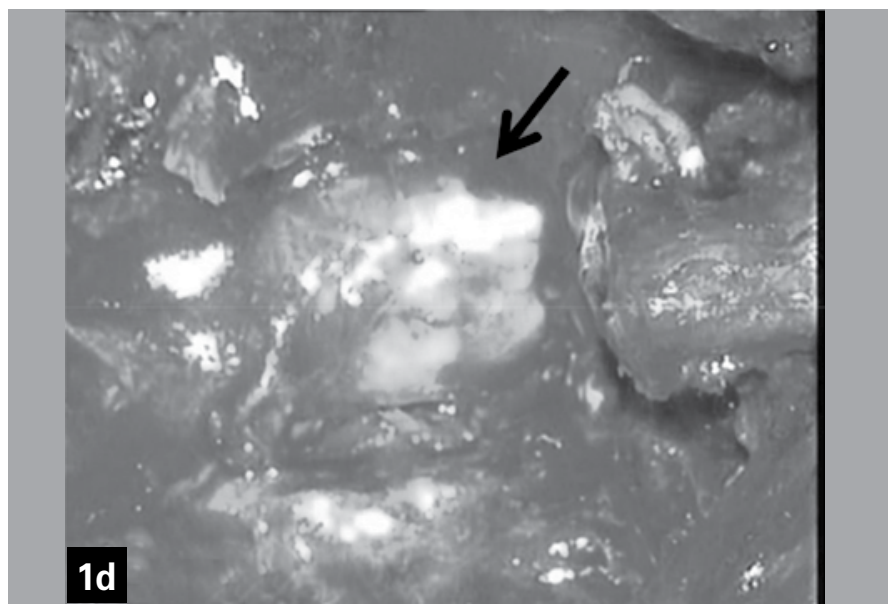

Figure 1d. Intraoperative view revealing a huge sequestrated disc fragment on the dural sac.

\section{CASE 2}

A 57year-old male was referred with chief complain of bilateral radiculopathy in the lower extremity. Pain had characteristics of L5 root sciatica and was more prominent on the right side. The scenario was started after lifting a heavy object. Neurological examination revealed decrease in force of dorsiflexion of the right foot with the score of $3 / 5$.

$M R I$ revealed L4L5 disc protrusion with mild retrolisthesis of L4 on L5, Posteriorly, the dural sac was compressed with a mass. This mass was isointense both in T1 and T2 images (Figures 2a, $2 \mathrm{~b}$ and $2 \mathrm{c}$ ). Diagnosis of posteriorly migrated disc fragment was made. This was confirmed after partial L4 laminectomy (Figure 2d). Subsequent to removal of such a rather big fragment, L4-L5 disc was exposed from the right side. There was a large tear in annulus; this was enlarged for removal of degenerated disc material. Later, the remnants of disc material were removed through the left side.

The patient made rapid recovery and was discharged in the second post -surgical day. Two weeks after surgery, he had made full recovery.

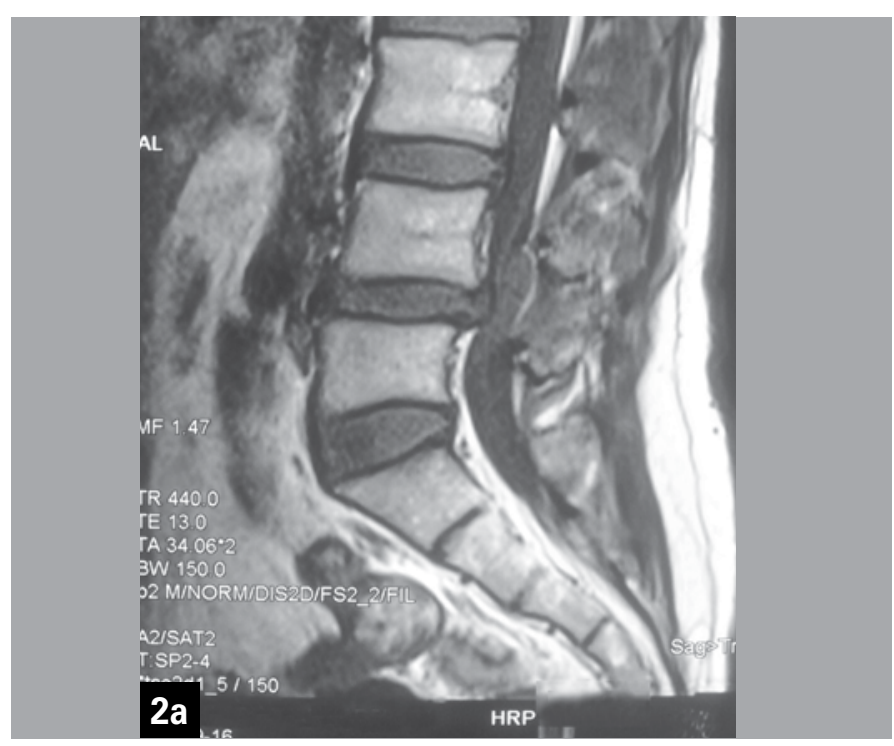

Figure 2a. Preoperative Sagittal T1-weight image of the lumbar spine revealing an isointense space occupying lesion located on posterior dural sac at L4-L5.

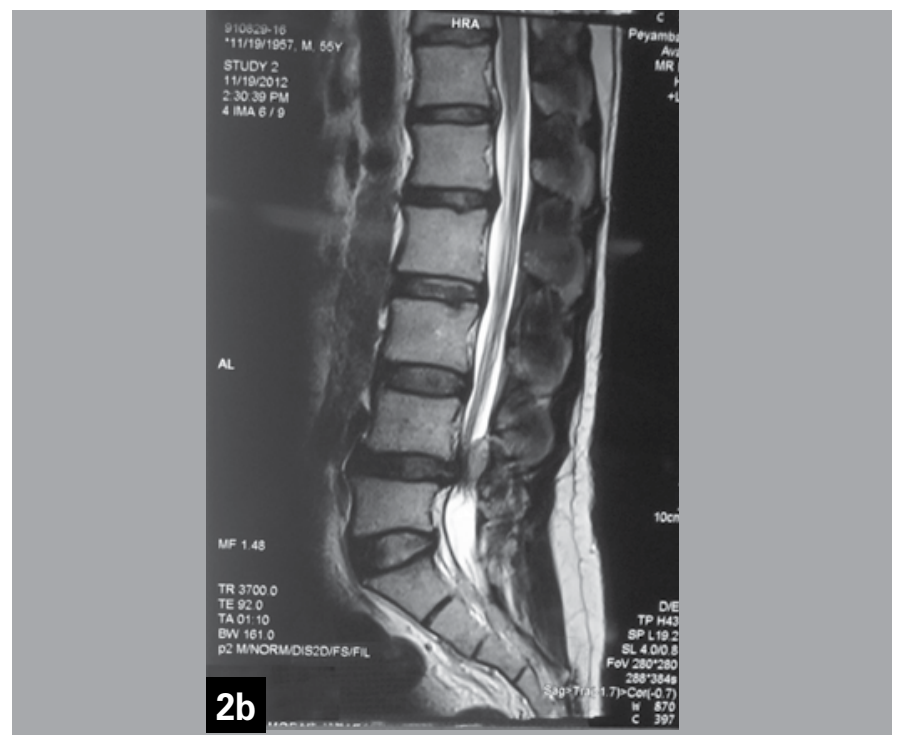

Figure 2b. Sagittal T2-weighted image showing the same mass with isointensity. 


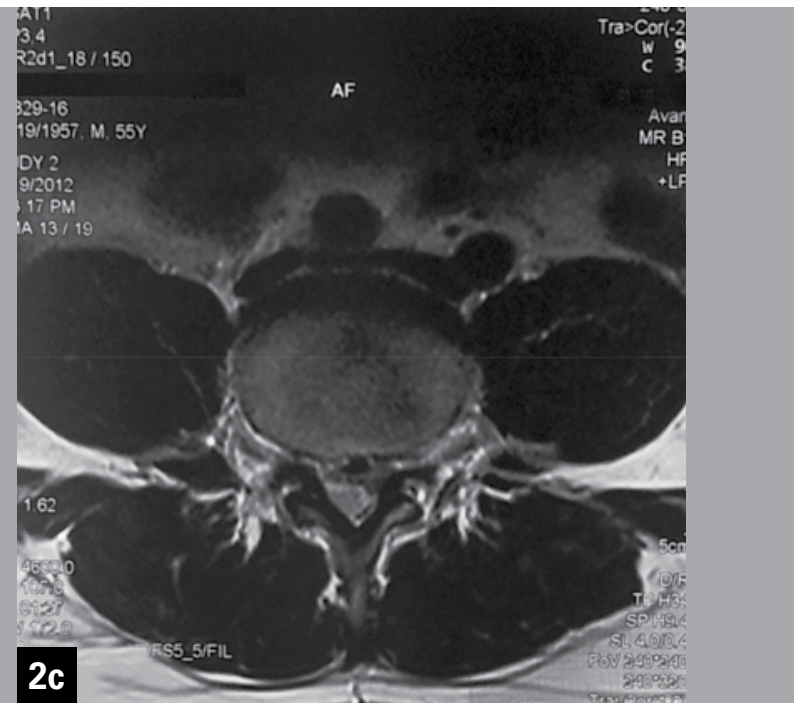

Figure 2c. Axial T2- weighted image obtained at the same level demonstrating right posterolateral location of the mass.

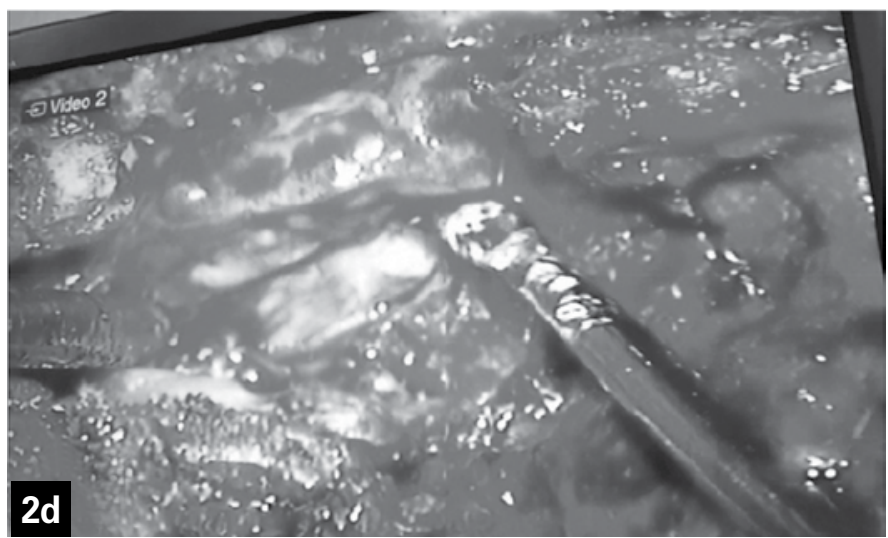

Figure 2d. Intraoperative view: showing an sequestrated disc fragment with loose adhesions to the dura.

\section{DISCUSSION}

Posterior epidural migration of a lumbar disc (PEM) is an uncommon event and less than 50 cases have been reported in the literature ${ }^{1-12 .}$

Posterior migration of a sequestered disc fragments is generally restricted by some anatomical constraints like PLL attachments, lateral and medial septums, epidural fat, epidural venous plexus and finally nerve roots $3,5,8,10$

In PEM of the lumbar disc, men outnumber the female with the ratio of 4 to 1 and the patients of middle age are mostly affected ${ }^{1,5,8,10-12}$.

The clinical picture of the event is either radiculopathy or cauda equina syndrome. Review of reported cases revealed that half of the cases were manifested with radiculopathy and the other half with cauda equina syndrome $e^{1-5,8,12}$.

The plain radiographs does not give too much information, in particular with consideration of disc height which remains normal because of the rapidity of the events in PEM. MRI is the best tool for detection of a posteriorly migrated disc fragment. In T1 weighted images, PEM is demonstrated as an isointense mass, with the signal intensity relatively similar to the intensity of intervertebral disc. However, in T2- weighted images, its intensity is variable and can be shown as a hyperintense mass in about $80 \%$ of the cases and hypointense or isointense in the remaining $20 \%$ cases $^{1,3,9}$

In contrasted MRI, particularly if the a few days passes, it resembles a cyst like lesion with rim enhancement,. This phenomenon is due to wrapping of the sequestrated disc by newly formed vessels or neovascularization $3,5,8,10$.

Since these radiological features mimic those of other common posterior epidural lesions, definite preoperative diagnosis cannot be made in all of the cases 3,10

Differential diagnosis based both on clinical and radiological features include rapid expansion of a pre-existing synovial cyst hemorrhagic juxtafacet cysts, gout, cystic schwannomas, tumors and abscess ${ }^{1,3-5,6,8-10}$

Decision for urgent surgery should be the first step toward the elimination of pain and averting neurological deficit, particularly in the subjects with cauda equina syndrome. Removal of the sequestrated disc fragment can be achieved through hemilaminectomy ${ }^{1,5,6}$

Hopefully, the outcome is good in majority of the patients suffering from this pathology. In particular, cauda equina syndrome resulting from PEM disc fragment has much more better prognosis than those with the same syndrome resulting from an anteriorly extruded disc fragment. Review of the literature revealed that majority of the PEM patients have recovered fully within weeks to a few months after surgery, probably because of abundant epidural fat which provides suitable space posteriorly $1,2,4,6,9$.

In conclusion, PEM should be included in differential diagnosis of all patients with acute radiculopathy or cauda equina syndrome despite its rarity. Prompt surgical intervention is justified particularly in those with cauda equina syndrome. Obviously, surgery should not be postponed for unnecessary further radiological investigations.

\section{REFERENCES:}

1. Akhaddar A, El-Asri A, Boucetta M. Posterior epidural migration of a lumbar disc fragment: a series of 6 cases. J Neurosurg Spine. 2011;15(1):117-28.

2. Bonaroti EA, Welch WC. Posterior epidural migration of an extruded lumbar disc fragment causing cauda equina syndrome. Clinical and magnetic resonance imaging evaluation. Spine (Phila Pa 1976). 1998;23(3):378-81.

3. Chen $\mathrm{CY}$, Chuang YL, Yao MS, Chiu WT, Chen $\mathrm{CL}$, Chan WP. Posterior epidural migration of a sequestrated lumbar disk fragment: MR imaging findings. AJNR Am J Neuroradiol. 2006:27(7):1592-4

4. Dösoğlu M, Is M, Gezen F, Ziyal MI. Posterior epidural migration of a lumbar disc fragment causing cauda equina syndrome: case report and review of the relevant literature. Eur Spine J. 2001;10(4):348-51.

5. El Asri AC, Naama O, Akhaddar A, Gazzaz M, Belhachmi A, El Mostarchid B,et al. Posterior epidural migration of lumbar disk fragments: report of two cases and review of the literature. Surg Neurol. 2008;70(6):668-71.

6. Elgamri A, Sami A, Aqqad A, Hilmani S, Ibahioin K, Naja A, et al. [Posterior migration of a

lumbar disc herniation as a cause of cauda equina syndrome]. J Radiol. 2009;90(6):731-3. 7. Kuzeyli K, Cakir E, Usul H, Baykal S, Yazar U, Karaarslan G, et al. Posterior epidural migration of lumbar disc fragments: report of three cases. Spine (Phila Pa 1976). 2003;28(3):E64-7.

8. Lakshmanan P, Ahuja S, Lyons K, Howes J, Davies PR. Sequestrated lumbar intervertebra disc in the posterior epidural space: a report on two cases and review of the literature. Spine J. 2006:6(5):583-6.

9. Carvi y Nievas MN, Hoellerhage HG. Unusual sequestered disc fragments simulating spinal tumors and other space-occupying lesions. Clinical article. J Neurosurg Spine. 2009;11(1):42-8

10. Robe P, Martin D, Lenelle J, Stevenaert A. Posterior epidural migration of sequestered lumbar disc fragments. Report of two cases. J Neurosurg. 1999;90(Suppl 2):264-6.

11. Sengoz A, Kotil K, Tasdemiroglu E. Posterior epidural migration of herniated lumbar disc fragment. J Neurosurg Spine. 2011:14(3):313-7.

12. Tatli M, Güzel A Ceviz A Karadağ O. Posterior epidural migration of sequestered lumbar disc fragment causing cauda equina syndrome. Br J Neurosurg.2005;19(3):257-9.

\section{ERRATA}

O artigo "Análisis comparativo de pacientes con estenosis degenerativa lumbar pura (EDLP) y estenosis secundaria a espondilolistesis degenerativa lumbar (ELDL) tratados quirúrgicamente en el período de 2008 a 2011 en el Hospital Metropolitano de Quito-Ecuador" publicado revista Coluna/Columna, na edição Volume 11, número 2, Abr/Jun 2012, pág.156-9, por solicitação do autor foi alterada a ordem dos autores. Onde se lê: Jaime Moyano ${ }^{1}$, Edison Ahtty ${ }^{1}$, Madelin Bilbao², Sebastián De la Torre ${ }^{3}$, o correto é: Sebastián De La Torre $^{1}$, Jaime Moyano ${ }^{2}$, Edison Ahtty², Madelin Bilbao ${ }^{3}$. 